\title{
IMPLEMENTASI HAK EKONOMI SOSIAL DAN BUDAYA MASYARAKAT ADAT DALAM HUKUM HAM INTERNASIONAL DI INDONESIA
}

\section{Ikbal}

Dosen Fakultas Hukum Univ. Tadulako, Palu

\begin{abstract}
Abstrak
Komitmen untuk menghormati dan melindungi hak-hak masyarakat adat (indigenous peoples) tidak dapat dilihat dari sudut pandang regional atau nasional semata. Permasalahan masyarakat adat saat ini telah menjadi perhatian global sebagaimana terwujud dalam berbagai bentuk instrumen internasional baik berupa deklarasi, konvensi, kovenan, maupun standar internasional lainnya. Demikian halnya dengan hak ekonomi, sosial, dan budaya merupakan bagian yang esensial dari hukum internasional tentang HAM. Hak ini mendapatkan pengaturan secara khusus dalam International Covenant on Economic Social and Cultural Rights (ICESCR).
\end{abstract}

Kata Kunci : Hak Ekonomi, Sosial, Budaya, dan Masyarakat adat.

\section{PENDAHULUAN}

Disadari atau tidak, eksistensi masyarakat adat ${ }^{1}$ (indigenous peoples $^{2}$ ) sampai saat ini terindikasi masih sering terabaikan dalam kehidupan bernegara. Dalam hal ini, masih terdapat negara yang tidak mempunyai perundangan dan mekanisme yang cukup memadai untuk mengakui dan melindungi hak-

\footnotetext{
1 Yang dimaksud masyarakat adat dalam tulisan ini adalah: kelompok masyarakat yang memiliki asal usul leluhur (secara turun temurun) di wilayah geografis tertentu, serta memiliki sistem nilai, ideologi, ekonomi, politik, budaya, sosial dan wilayah sendiri. Istilah ini dirumuskan oleh pertemuan yang dihadiri oleh beberapa kepala adat serta para aktivis hak-hak masyarakat adat pada tahun 1993 di Tanah Toraja. Lihat Sugeng Bahgijo dan Asmara Nababan (ed.), Hak Asasi Manusia: Tanggung Jawab Negara, Peran institusi Nasional dan masyarakat, Komisi Nasional Hak Asasi Manusia, Jakarta, 1999, hlm. 136.

${ }^{2}$ Masyarakat adat dipilih sebagai terjemahan dari indigenous peoples untuk menyamakan istilah yang sering digunakan secara berlainan.
}

hak masyarakat adat, bahkan di negara-negara dimana norma-norma hukum telah diikuti dan dilengkapi oleh mekanisme implementasi atau telah menetapkan prosedur penyelesaian sengketa yang konkrit, mekanisme tersebut belum sungguhsunguh diterapkan karena didominasi kepentingan ekonomi dan politik. Dalam banyak kasus, hal ini diakibatkan oleh upaya negaranegara untuk mengejar pembangunan ekonomi, bersama dengan kebutuhan ekonomi global, sehingga memacu meningkatnya kebutuhan SDA yang tinggi yang berujung pada pencarian global terhadap SDA di seluruh dunia, hingga masuk ke wilayahwilayah masyarakat adat.

Bagi masyarakat adat, dengan masuknya proyek-proyek SDA di wilayah mereka telah berdampak pada tatanan kehidupan ekonomi, sosial dan budaya sebagai akibat dari tuntutan pembangunan. Karena sebagian besar proyek pembangunan tersebut lebih ditujukan untuk kepentingan pemerintah, perusahaan- 
perusahaan multinasional dan penduduk non-masyarakat adat. Akibat pelaksanaan proyek-proyek tersebut, mereka terpaksa meninggalkan tanahnya, dan dipaksa untuk pindah dan menetap di wilayah yang bukan pilihan mereka.

International

Labour

Organisation No. 169 Concerning Indigenous and Tribal Peoples in Independent Countries 1989 (Konvensi ILO 169) ${ }^{3}$ dapat dilihat sebagai suatu hasil dari gerakan menuju ketanggapan terhadap tuntutan masyarakat adat melalui hukum HAM internasional. Pasal 13 ayat (1) Konvensi ini berbunyi:

"Pemerintah

haruslah menghormati makna yang khusus bagi nilai-nilai budaya dan spiritual dari masyarakat adat yang terkait, yakni makna khusus dari hubungan mereka dengan tanah atau wilayah, atau keduanya, yang mereka tinggali atau gunakan, dan khususnya aspek kolektif dari hubungan ini"

Sifat yang khas dari hubungan masyarakat adat dengan tanahnya juga diungkap dalam United Nations Declaration on the Rights of Indigenous Peoples ${ }^{4}$ (UNDRIP).

\footnotetext{
${ }^{3}$ Konvensi ILO 169 pada Pasal 1 (1.a) dan (1.b) menggunakan istilah tribal peoples dan indigenous peoples. Sejalan dengan rumusan dalam Konvensi ini, menurut Sandra Moniaga, di Indonesia mayoritas penduduk merupakan bangsa pribumi, tetapi tidak semua warga pribumi adalah masyarakat adat. Lihat Sugeng Bahgijo dan Asmara Nababan, Op.cit., hlm. 137.

4 Deklarasi Perserikatan Bangsa-Bangsa tentang Hak-Hak Masyarakat Adat, telah diadopsi Sidang Umum (SU) PBB pada sesi ke-61 pada Kamis 13 September 2007, dengan dukungan 144 suara, 4 menentang dan 11 abstein. Lihat Sem Karoba, Hak
}

Secara khusus Pasal 25 deklarasi ini berbunyi:

"Masyarakat adat memiliki hak untuk memelihara dan memperkuat hubungan spritual dan material mereka dengan tanah, wilayah, air dan pantai serta sumberdaya lainnya yang secara tradisional mereka miliki atau tinggali atau gunakan, dan untuk menujunjung tinggi tanggung jawab mereka bagi generasi mendatang".

Pentingnya penegakan dan penaatan terhadap hukum internasional di atas khususnya dalam menjamin perlindungan hak masyarakat adat, maka hukum nasional mempunyai peran dalam mengatasi persoalan tersebut. Namun demikian, penerapan hukum internasional kedalam masyarakat nasional suatu negara, bukanlah perkara yang mudah. Sebab dalam struktur masyarakat internasional, terdapat sejumlah negara-negara nasional yang masing-masing memiliki kedaulatan hukum.

Terkait hal di atas, menurut Mochtar Kusumaatmadja, ${ }^{5}$ persoalan tempat hukum internasional dalam keseluruhan tata hukum secara umum merupakan persoalan menarik, baik dilihat dari sudut teori atau ilmu hukum maupun dari sudut praktis, sebab hukum internasional merupakan hukum pada umumya. Selanjutnya menurut Mochtar, anggapan atau pendirian itu tidak dapat dihindarkan apabila kita

Asasi Masyarakat Adat, Galangpress, Yogyakarta, 2007, hlm. 73.

5 Mochtar Kusumaatmadja dan Etty R. Agoes, Pengantar Hukum Internasional, Edisi Kedua, Cetakan Ke-1, Alumni, Bandung, 2003, hlm. 55. 
hendak melihat hukum internasional benar-benar hidup dalam kenyataan, sehingga mempunyai hubungan yang efektif pula dengan hukum nasional suatu bangsa. ${ }^{6}$

Penerapan hukum internasional suatu bangsa tentu saja akan menimbulkan benturan dengan kedaulatan negara, sebab kemerdekaan suatu negara adalah konsekuensi dari adanya kedaulatan. ${ }^{7}$ Menurut Yudha Bhakti Ardhiwisastra $^{8}$, bahwa kedaulatan suatu negara direfleksikan atau diterapkan melalui pelaksanaan yurisdiksi negara dalam batas wilayahnya. Di dalam masyarakat internasional terdapat sejumlah negara yang merdeka, dan masingmasing negara tersebut mempunyai kedaulatan, termasuk kedaulatan untuk membuat dan melaksanakan hukum di wilayahnya. Dalam hal ini Yudha Bhakti Ardhiwisastra ${ }^{9}$ menyatakan, bahwa masalah kedaulatan merupakan suatu hal yang tidak dapat dicabut karena merupakan masalah sumber validitas hukum internasional, disamping merupakan masalah filsafat hukum. Artinya masalah ini tidak dapat dipecahkan hanya melalui kajian teori-teori normatif saja atau sekedar pembentukan peraturan-peraturan. Diterapkannya kedaulatan yang bersifat mutlak akan berarti penolakan terhadap konsep tentang tata hukum internasional bagi umat manusia, yaitu masyarakat negara-

\footnotetext{
${ }^{6}$ Ibid.

${ }^{7}$ Mochtar Kusumaatmadja, Pengantar Hukum Internasional, Buku-1 Bagian Umum, Bina Cipta, Bandung, 1990, hlm .41. ${ }^{8}$ Yudha Bhakti Ardhiwisastra, Hukum Internasional: Bunga Rampai, Alumni, Bandung, 2003, hlm. 98.

${ }^{9}$ Yudha Bhakti Ardhiwisastra, Imunitas Kedaulatan Negara di Forum Pengadilan Asing, Alumni, Bandung, 1999, hlm. 46.
}

negara yang memiliki derajat yang sama. Sejalan dengan pandangan tersebut meskipun negara-negara memiliki kedaulatan dan hukum nasional dalam hubungannya dengan hukum internasional, Mochtar Kusumaatmadja juga berpendapat bahwa hukum nasional tunduk kepada hukum internasional. ${ }^{10}$

Berangkat dari uraian latar belakang di atas maka persoalan yang dikedepankan dalam tulisan ini adalah bagaimanakah implementasi hukum HAM internasional dalam melindungi hak ekonomi, sosial dan budaya masyarakat adat di Indonesia?

\section{PEMBAHASAN}

Secara teoritis, persoalan hubungan antara hukum internasional dan hukum nasional merupakan hal yang perlu dikaji, mengingat teori ini berkaitan dengan pengaruh masuknya beberapa instrumen internasional yang berkaitan dengan HAM kedalam hukum nasional.

Adanya dua pandangan tentang hukum internasional yaitu pandangan yang dinamakan voluntarisme, yang mendasarkan berlakunya hukum internasional bahkan persoalan ada atau tidaknya hukum internasional ini pada kemauan negara, dan pandangan obyektivis yang menganggap ada dan berlakunya hukum internasional ini lepas dari kemauan negara. ${ }^{11}$ Dalam hal hukum internasional berhadapan dengan sistem hukum nasional, tidak ada

\footnotetext{
${ }^{10}$ Mochtar Kusumaatmadja dan Etty R. Agoes, Op.Cit., hlm. 64.

${ }^{11}$ Mochtar Kusumaatmadja, Pengaturan Hukum Masalah Lingkungan Hidup: beberapa pikiran dan Sarana, Alumni, Bandung, 1975, hlm 40.
} 
peraktek yang seragam dan universal yang menentukan bagaimana negaranegara seharusnya memasukkan hukum internasional kedalam sistem hukum nasionalnya. ${ }^{12}$ Dalam hubungan ini Akehurst menyatakan: ${ }^{13}$

"There is a general duty of state to bring domestic law into conformity with obligation under international law. But international law level the method of achiieving this result (described in literature by varying concept of incorporation, adaption, transformations or reception) to be domestic jurisdiction of states"

Maksud pendapat di atas, bahwa negara memiliki kewajiban untuk menyesuaikan hukum nasionalnya dengan kewajibankewajiban-kewajiban di bawah hukum internasional. Hukum internasional dapat menjadi hukum nasional melalui inkorporasi, adopsi, transformasi atau resepsi, yang dalam pelaksanaannya ditentukan oleh masing-masing negara berdasarkan perundang-undangan nasionalnya.

Di antara cara-cara berlakunya hukum internasional kedalam hukum nasional di atas, teori transformasilah yang banyak dibicarakan. Menurut teori ini, hukum internasional baru dapat berlaku dalam lingkup nasional suatu negara, manakala hukum internasional itu telah ditransformasi-

\footnotetext{
${ }^{12}$ Rebecca M. Wallace, Hukum Internasional, Bambang Arumanadi (Penerjemah),Cetakan 1, IKIP Semarang Press, Semarang, 1993, hlm. 37.

${ }^{13}$ Peter Malanczuk, Akehurst's A Modern Introductions to International Law, $7^{\text {th }}$ Revised Ed, Routledge, London, 1997, hlm. 64.
}

kan kedalam hukum nasional, ${ }^{14}$ sehingga tidak lagi merupakan hukum internasional, tetapi telah menjadi bagian dari hukum nasional. Hukum internasional mempunyai dasar kekuatan hukum mengikat, sementara proses transformasinya diserahkan kepada tata cara menurut perundang-undangan negara yang bersangkutan.

Selain teori transformasi, dikenal pula teori inkorporasi. Praktik ini merupakan perkembangan dari the Blackstonian Doctrine yang dikembangkan oleh Sir William Blackstone yang kemudian lebih dikenal sebagai Incorporation Doctrine. Doktrin ini menganggap bahwa hukum kebiasaan internasional sebagai bagian dari common Law, sehingga dapat langsung diberlakukan tanpa perlu persyaratan apapun. ${ }^{15}$ Dalam hal ini Blackstone menyatakan sebagai berikut: "the law of nations, wherever any question arise wich is properly the object of its jurisdiction is here adopted in its full extent by the common law, and it is held be part of the law of the land." 16 Maksudnya bahwa hukum antar bangsa dalam masalah yang berkaitan dengan yurisdiksi, menurut sitem hukum common law hal itu dianggap sebagai bagian dari hukum negara.

Teori inkorporasi lahir dan berkembang di Inggris, dan digunakan oleh para hakim dalam mengadili perkara. Teori ini menganggap bahwa hukum

\footnotetext{
${ }^{14}$ Mochtar Kusumaatmadja, Pengantar Hukum Internasional, Op.Cit., hlm .41.

${ }^{15}$ Melda Kamil Ariadno, Hukum Internasional Hukum Yang Hidup, Diadit Media, Jakarta, 2007, hlm. 65.

${ }^{16}$ Dalam J.G. Starke, An Introduction to International Law, $8^{\text {th }}$ ed, London, 1977, hlm. 90 .
} 
internasional adalah hukum negara (Inggris), oleh karena itu bilamana hukum tidak menemukan hukumnya dalam sistem hukum nasional terhadap suatu perkara yang diajukan kepadanya, maka ia terikat dan wajib untuk mengikuti hukum internasional, tanpa mempersoalkan apakah hukum internasional itu telah direduksi atau belum kedalam hukum nasional. $^{17}$

Praktik di Inggris menganggap hukum kebiasaan internasional sebagai bagian dari hukum nasional (the Law of the Land) sehingga dapat diberlakukan di Pengadilan Inggris dengan memenuhi persyaratan sebagai berikut:

1. Ketentuan tersebut tidak bertentangan dengan peraturan peraturan Inggris, baik peraturan yang telah telah ada lebih dulu maupun yang sesudahnya.

2. Ketentuan-ketentuan hukum kebiasaan yang btelah diterima dalam keputusan pengadilan Inggris akan mengikat pengadilan-pengadilan

sesudahnya. Meskipun kemudian ketentuan-ketentuan hukum kebiasaan internasional itu berubah.

Kedua persyaratan di atas harus dipenuhi oleh semua pengadilan Inggris dalam mempertimbangkan penerimaan ketentuan hukum internasional, meskipun terkadang hasilnya merupakan penolakan atau pelanggaran dari hukum internasional. $^{18}$

Terkait dengan cara-cara berlakunya hukum internasional ke dalam sitem hukum nasional Indonesia, maka hal ini tidak diatur

17 Mochtar Kusumaatmadja dan Etty R. Agoes, Op.Cit., hlm. 82

${ }^{18}$ Melda Kamil Ariadno, Loc.Cit. secara tegas dalam UUD 1945. Dalam hal ini Mochtar Kusumaatmadja menyatakan, satusatunya petunjuk mengenai hal itu, harus didasarkan pada praktek berkenaan dengan pelaksanaan kewajiban sebagai peserta perjanjianperjanjian internasional yang telah diadakan. ${ }^{19}$ Berdasarkan petunjuk itu, Indonesia tidak menganut teori transformasi, melainkan teori inkorporasi. Indonesia lebih condong pada sistem negara-negara Eropa Kontinental, yang langsung menganggap negara terikat kepada kewajiban melaksanakan dan menaati semua ketentuan perjanjian dan konvensi yang telah disahkan tanpa perlu mengundangkan lebih lanjut dalam bentuk peraturan pelaksanaan (implementing legislation). ${ }^{20}$ Tetapi beliau mengakui bahwa dalam beberapa hal pengundangan dalam undang-undang nasional adalah mutlak diperlukan. ${ }^{21}$

Meskipun Indonesia menganut sistem hukum Eropa Kontinental, dilihat dari sudut efektifitas dan tujuan berlakunya hukum, maka dalam praktek ketatanegaraan Indonesia, tidak semua ketentuanketentuan hukum internasional yang telah diratifikasi dengan sendirinya efektif berlaku. Hanya ketentuanketentuan yang menyangkut negara sebagai institusi publik saja yang langsung berlaku dan mengikat. Sementara ketentuan hukum internasional yang sifatnya menyangkut masyarakat sebagai individu, tidak dengan sendirinya berlaku, tetapi memerlukan transformasi lebih lanjut (legislasi).

\footnotetext{
${ }^{19}$ Ibid., hlm. 92.

${ }^{20}$ Ibid., hlm 92-93.

21 Mochtar Kusumaatmadja, Pengaturan Hukum Masalah..., Op.cit., hlm 57.
} 
Dalam perdebatan teori transformasi dan inkorporasi, Endang Saefullah $^{22}$ juga berpendapat, dalam masalah hubungan antara perjanjian internasional/hukum internasional dengan hukum nasional, dalam praktek, Indonesia menganut paham baik inkorporasi maupun transformasi, tidak menganut salah satu diantaranya secara mutlak. Inkorporasi berlaku bagi perjanjianperjanjian internasional yang hanya mengikat negara atau badan negara, sedangkan transformasi berlaku bagi perjanjian-perjanjian internasional yang mengikat langsung warga negara secara individual dan badan hukum/badan usaha.

Dengan demikian, bila hendak melihat terwujudnya aturan-aturan hukum internasional dalam tatanan hukum nasional yang merupakan bagian dari hukum nasional. Kedua teori tersebut hendaknya dapat dipadukan, tergantung pada sasaran akhir dari ketentuan hukum internasional, yaitu apakah negara sebagai institusi publik atau masyarakat sebagai perseorangan. Jika ketentuan hukum internasional itu adalah menyangkut masyarakat sebagai individu, maka ratifikasi yang telah dilakukan oleh negara harus ditransformasikan lebih lanjut kedalam perundang-undangan nasional yang lebih konkrit dan operasional.

Kecendrungan umum saat ini adalah prakarsa perlindungan HAM yang bermula pada tingkat

22 Endang Saefullah Wiradipraja, "Konsekuensi Yuridis Keanggotaan Indonesia dalam WTO-GATS dan Pengaruhnya Terhadap Industri dan Perdagangan Jasa", Jurnal Hukum Internasional, Vol.1 No.1 Tahun 2002, Bagian Hukum Internasional Fakultas Hukum Universitas Padjajaran UNPAD, hlm. 1-16. internasional untuk kemudian ditindak lanjuti pada tingkat nasional. Singkatnya, bahwa hukum HAM internasional dapat menjadi tambahan aturan HAM nasional.

Terdapat beberapa mekanisme atau prosedur sehungga normanorma hukum HAM internasional dapat diterapkan terkait dengan perlindungan hak-hak masyarakat adat. Dalam hukum perjanjian internasional yang diatur dalam Konvensi Wina 1969, ratifikasi merupakan salah satu cara pengikatan diri suatu negara dalam perjanjian internasional yang diakui oleh hukum internasional, di samping cara lainnya yaitu, aseptasi, aproval, dan aksesi. ${ }^{23}$ Namun demikian, hukum internasional tidak memberikan landasan bagaimana prosedur sebuah negara melakukan ratifikasi. Dalam hubungan ini hukum internasional hanya memberikan pengukuhan bahwa cara-cara pengesahan perjanjian tersebut diakui validitasnya manakala sebuah negara melakukan salah satu cara di atas. Artinya, jika negara mengesahkan perjanjian internasional dengan cara-cara di atas, maka memiliki akibat yaitu lahirnya hak dan kewajiban negara dalam hukum internasional. ${ }^{24}$ Ratifikasi merupakan prosedur hukum nasional yang ditentukan menurut sistem ketata negaraan dari masing-masing-negara. ${ }^{25}$

\footnotetext{
23 Pasal 2 angka 1 Konvensi Wina 1969. Ketentuan yang sama juga terdapat dalam UU No. 24 tahun 2000 tentang Perjanjian Internasional.

24 Sumaryo Soryo kusumo, Studi Kasus Hukum Internasional, Tata Nusa, Jakarta, 2007, hlm. 41

${ }^{25}$ Harjono, Politik Hukum Perjanjian Internasional, Bina Ilmu, Suarabaya, 1999, hlm. 131.
} 
Beberapa standar internasional yang dapat diterapkan terhahadap perlindungan hak-hak masyarakat adat adalah Kovensi ILO No. 169 tahun 1989, dan ICESCR, ketentuanketentuan ini untuk mengefektifkan berlakunya dalam hukum nasional memerlukan ratifikasi terlebih dahulu. Sedangkan UNDRIP tidak memerlukan ratifikasi ataupun aksesi karena memang tidak terdapat isyarat tentang hal itu.

Namun demikian, salah satu kendala perlindungan hak masyarakat adat melalui mekanisme hukum HAM internasional di Indonesia saat ini adalah belum diratifikasinya Konvensi ILO 169. Dengan demikian, pemerintah tidak memiliki kewajiban hukum untuk mengimplemetasikan ketentuan konvensi tersebut dalam hukum nasionalnya.

Sejauh ini pemerintah telah meratifikasi beberapa perjanjian internasional, diantaranya adalah ICESCR melaui UU No 11 tahun 2005 tentang Pengesahan Kovenan Hak Ekonomi, Sosial dan Budaya, melalui instrumen pengikatan terhadap perjanjian internasional yaitu accession. Konsekuensi dari pengikatan diri terhadap perjanjian tersebut tentunya akan mengakibatkan pemerintah Indonesia harus mengimplementasikan ketentuan dan substansi ICESCR dalam perundang-undangannya. Implementasi dalam hal ini dapat berupa pemenuhan kewajiban dalam membuat peraturan yang melindungi hak asasi warga negara, dapat pula berupa efektifitas pelaksanaan dari peraturan yang telah ada sebelumnya. Dalam rangka mengimplementasikan instrumen HAM internasional, berdasarkan traktat yang terkait, negara diwajibkan untuk memasukkan laporan tentang kinerja mereka dalam mengimplementasikan perjanjian tersebut. Dalam sistem ILO, laporan negara diperiksa oleh Komite Ahli tentang Penerapan Konvensi dan Rekomendasi. Organisasi-organisasi pekerja dan majikan dinegara-negara yang telah meratifikasi konvensi-konvensi ILO dapat juga memasukkan komentarkomentar tentang aplikasi dari konvensi-konvensi tersebut. Sebagai contoh, pada tahun 1970, Organisasi Pekerja Kolombia meminta perhatian ILO terhadap tindakan-tindakan penyiksaan terhadap masyarakat adat, dan terhadap tindakan pengambilan tanah hak milik masyrakat adat di daerah Planas (Kolombia). Contoh lain adalah komunikasi atau laporan yang disampaikan oleh Federasi Internasional Perkebunan, Pertanian dan Persatuan Pekerja pada tahun 1989. Sehubungan dengan adanya serangkaian proyek pembangunan yang telah dilaksanakan atau direncanakan di India yang mengakibatkan pemindahan antara 2 sampai 3 juta masyarakat adat, dan bahwa tidak ada kelengkapan memadai yang disiapkan untuk relokasi dan rehabilitasi mereka. Jika Komite ILO ini menemukan permasalahan atau kekurangan dalam praktik-praktik negara, Komite dapat melakukan pengamatan-pengamatan yang hasilnya dipublikasikan dalam laporan tahunan Komite kepada Konfrensi Buruh Internasional. ${ }^{26}$

Dalam sistem ICESCR kewajiban negara peratifikasi adalah membuat laporan kepada Komite Hak Asasi Manusia dalam waktu

${ }^{26}$ Rafael Edi Bosko, Op.cit., hlm. 147. 
satu tahun setelah konvensi ini berlaku dalam hal langkah-langkah yang telah diambil dalam pemenuhan hak-hak yang diatur oleh masingmasing kovenan bagi warganya. ${ }^{27}$ Hal ini merupakan konkretisasi dari kewajiban negara mengimplementasikan ketentuan ICESCR ditingkat internasional.

Dalam lingkup nasional, kewajiban negara peratifikasi untuk mengimplementasikan ketentuan ICESCR adalah berupa jaminan atas terselengarakannya hak-hak suatu bangsa yang sebenarnya merupakan rakyat atau warga negara pada umumnya dan masyarakat adat khususnya. Secara normatif kewajiban ini merupakan manifestasi dari hak setiap orang untuk menetukan nasibnya sendiri , sebagaimana disebutkan dalam Pasal 1 ICCPR bahwa: "Semua bangsa berhak untuk menentukan nasib sendiri. Berdasarkan hak tersebut mereka bebas untuk menentukan status politik mereka dan bebas untuk mengejar kemajuan ekonomi, sosial dan budaya mereka".

Terkait dengan implementasi ICCPR, sebagaimana dikemukakan oleh Rafael Edi Bosko, bahwa Komite Hak Asasi Manusia ketika mempertimbangkan laporan sebuah negara telah mengartikan Pasal 27 ICCPR dalam arti yang lebih luas. Sehubungan dengan penerapan Pasal 27 tersebut, Komite Hak Asasi Manusia telah mengajukan pertanyaan-pertanyaan yang tidak hanya mengenai hak-hak minoritas dan aspek-aspek hak yang secara jelas tercakup dalam pasal tersebut, taetapi juga tentang isu-isu yang membawa kepada interpretasi yang lebih luas dari rumusan Pasal 27

\footnotetext{
${ }^{27}$ Pasal 16,17 ICESCR.
}

yang limitatif. Dalam hal ini Komite Hak Asasi Manusia telah menegaskan bahwa toleransi dan non-diskriminasi tidaklah cukup bagi terealisasinya hak-hak minoritas, tetapi harus menuntut bahwa negara harus mengambil tindakan-tindakan yang secara aktif memajukan hakhak minoritas, termasuk minoritas masyarakat adat yang mencakup isu hak atas tanah, hak atas sumberdaya alam dan lingkungan masyarakat adat. Contoh kasus dalam hal ini, ketika Komite Hak Asasi Manusia membahas laporan periode ketiga dari Ekuador, meminta perwakilan dari negara tersebut untuk meberikan informasi tentang bagaimana kemorosotan ekologi diwilayah Amazon mempengaruhi organisasi sosial budaya masyarakat adat yang tinggal di sana dan tentang tindakantindakan yang diambil untuk mengatasi permasalahan tersebut. Isu tentang kepemilikan tanah secara kolektif terhadap tanah juga dibahas ketika Komite Hak Asasi Manusia membahas laporan Kolombia. ${ }^{28}$

Berdasarkan

ketentuanketentuan di atas, adanya keterkaitan antara hak menetukan nasib sendiri dalam rangka pemenuhan hak ekonomi, sosial dan budaya masyarakat adat sebagai bagian rakyat yang berada dalam suatu bangsa (negara), maka mereka bebas untuk menentukan hak ekonomi, sosial dan budayanya. Demikian pentingnya hak-hak tersebut bagi masyarakat adat sehingga dalam pembangunan nasional yang dilaksanakan sesuai dengan situasi dan kondisi sosial serta kebutuhan

28 Athanasia Spilipolou Akermark, Justifications of Minority Protection in International Law, 1997, hlm. 139-140, sebagaimana dikutip dalam Rafael Edi Bosko, Op.cit., hlm. 143-144. 
masing-masing negara dalam rangka merealisasikan HAM pada umumnya dan hak masyarakat adat khususnya, negara diwajibkan untuk melaksanakannya tanpa pembedaan apapun yang didasarkan pada prinsip non-diskriminasi. ${ }^{29}$ Ini merupakan konkretisasi dari kewajiban implementasi hukum internasional ditingkat nasional.

Sebagai bagian dari kewajiban pemerintah Indonesia untuk mengimplementasikan kovenan internasional di tingkat nasional atas hak-hak warga negara, pemerintah diwajibkan untuk melakukan harmonisasi atas hukum nasionalnya dengan kovenan internasional. Harmonisasi yang dimaksud adalah dengan melakukan penyesuaian hukum nasional yang mengatur masalah terkait dengan pemenuhan hak yang ada di dalam kovenan. Penyesuaian tersebut dapat berupa melakukan legal reform terhadap aturan atau mengamandemen konstitusi yang tidak sesuai dengan kovenan. Penyesuaian dapat pula berarti memberlakukan peraturanperaturan baru yang diperlukan agar pemenuhan hak dan penghargaan HAM dapat dilakukan dengan baik. ${ }^{30}$

Dalam rangka harmonisasi hukum, sebagaimana dikatakan oleh Gusnu Goesniandhie, bahwa pembentukan peraturan perundangundangan yang dilaksanakan melalui harmonisasi hukum, akan selalu menyangkut baik substansi, struktur maupun kultur hukum. Penerimaan norma-norma hukum yang bersifat internasional yang hendak

${ }^{29}$ Pasal 2 ayat (2) ICESCR, dan Pasal 2 ayat (1) ICCPR

${ }^{30}$ Eko Riyadi dan Supriyanto Abdi (ed.), Mengurai Kompleksitas Hak Asasi Manusia: Kajian Multi Perspektif, PUSHAM UII, Yogyakarta, 2007, hlm. 529. diberlakukan di Indonesia perlu memperhitungkan sistem nilai budaya yang terdapat di Indonesia. Selanjutnya menurut Goesnadhie, bahwa harmonisasi sistem hukum dapat dilakukan terhadap sistem maupun substansinya. Berkenaan dengan hal tersebut menurut beliau, pembentukan peraturan perundangundangan yang baru dapat dilakukan dengan pendekatan penggunaan norma penunjuk dalam undangundang yang telah ada dengan berbagai modifikasi. Selain itu, peraturan perundang-undangan tersebut mengatur sesuatu hal yang sebelumnya memang belum diatur dalam peraturan perundangundangan di Indonesia. Dalam penggunan model-model hukum asing uniform laws, baik penggunaan itu berwujud pemakaian dalam bentuknya semula (adoption), maupun dalam bentuk yang sudah diubah (adaptation), diperlukan acuan dasar mengenai hukum-hukum internasional yang dapat mengakomodasi kebutuhan hukum nasional. Dengan demikian diharapkan akan tercipta peraturan perundang-undangan nasional yang harmonis dan dalam alur yang taat asas. $^{31}$

Dengan demikian, secara umum ratifikasi atas perjanjian internasional berarti pemerintah wajib untuk melakukan implementasi terhadap perjanjian tersebut. Dan sebagai konsekuensi dari ratifikasi tersebut adalah negara wajib mengejawantahkan prinsip-prinsip hak asasi manusia ke dalam hukum nasional, dalam arti mengubah UU

\footnotetext{
${ }^{31}$ Kusnu Goesnadhie, Harmonisasi Hukum dalam Perspektif Perundang-undangan, Temprina Media Grafika, Surabaya, hlm. 105.
} 
yang tidak sesuai dan membuat peraturan perudang-undangan baru.

\section{PENUTUP}

\subsection{Simpulan}

Implementasi hukum HAM internasional dapat dilakukan dengan cara meratifikasi perjanjian internasional. Dengan demikian, perjanjian internasional tersebut dapat diimplementasikan dalam produk perundang-undangan dengan melakukan penyesuaian hukum nasional yang mengatur masalah terkait dengan pemenuhan hak yang ada di dalam perjanjian tersebut. Penyesuaian tersebut dapat berupa melakukan legal reform terhadap undang-undang atau mengamandemen konstitusi yang tidak sesuai dengan kovenan, selain itu penyesuaian dapat pula berarti memberlakukan peraturan-peraturan yang baru.

\subsection{Saran}

Kewajiban pemerintah dalam mengimplementasikan hukum HAM internasional harus disertai dengan komitmen untuk melakukan pemenuhan hak yang dijamin di dalam hukum HAM internasional. Dalam hal ini, diharapkan kepada pemerintah perlu meratifikasi dengan segera Kovensi ILO 169, dengan demikian perlindungan hak masyarakat adat melalui hukum HAM internasional dapat dilaksanakan sebagaimana mestinya.

\section{DAFTAR PUSTAKA}

Adnan Buyung Nasution dan Patra M. Zen, 2006. Instrumen Internasional Pokok Hak Asasi Manusia, Yayasan Obor Indonesia, Jakarta,
Eko Riyadi dan Supriyanto Abdi (ed.), 2007. Mengurai Kompleksitas Hak Asasi Manusia: Kajian Multi Perspektif, PUSHAM UII, Yogyakarta.

Endang Saefullah Wiradipraja, 2002, Konsekuensi Yuridis

Keanggotaan Indonesia dalam WTO-GATS dan Pengaruhnya Terhadap Industri dan Perdagangan Jasa, Jurnal Hukum Internasional, Vol.1 No. 1

Harjono, 1999. Politik Hukum Perjanjian Internasional, Bina Ilmu, Surabaya.

Kusnu Goesnadhie, 2006. Harmonisasi Hukum dalam Perspektif Perundangundangan, Temprina Media Grafika, Surabaya.

Majda El Muhtaj, 2008, DimensiDimensi HAM: Mengurai Hak Ekonomi Sosial dan Budaya, Rajawali Pers, Jakarta.

Melda Kamil Ariadno, 2007. Hukum Internasional Hukum Yang Hidup, Diadit Media, Jakarta.

Mochtar Kusumaatmadja dan Etty R. 2003. Agoes, Pengantar Hukum Internasional, Edisi Kedua, Cetakan Ke-1, Alumni, Bandung.

Mochtar Kusuma Atmadja, 1975, Pengaturan Hukum Masalah Lingkungan Hidup: beberapa pikiran dan Sarana, Alumni, Bandung. 1990, Pengantar Hukum Internasional, Buku-1 Bagian Umum, Bina Cipta, Bandung. 
M. Ridha Shaleh, 2005, Ecocide, Politik Kejahatan Lingkungan dan Pelanggaran Hak Asasi Manusia, Walhi, Jakarta.

Muladi (ed), 2005, Hak Asasi Manusia, Hakikat, Konsep dan Implikasinya dalam Perspektif Hukum dan Masyarakat, Refika Aditama, Bandung.

Rafael Edi Bosko, 2006, Hak-Hak Masyarakat Adat dalam Konteks Pengelolaan Sumber Daya Alam, ELSAM, Jakarta.

Rakhmat Syafa'at, et.al, 2008. Negara, Masyarakat Adat dan Kearifan Lokal, Trans Publishing, Semarang.

Sem Karoba, 2007, Hak Asasi Masyarakat Adat, Galangpress, Yogyakarta.

Starke, J.G., 1977, An Introduction to International Law, $8^{\text {th }}$ ed, London.

Sugeng Bahgijo dan Asmara Nababan (ed.), 1999. Hak Asasi Manusia: Tanggung Jawab Negara, Peran institusi Nasional dan masyarakat, Komisi Nasional Hak Asasi Manusia, Yakarta.

Sumaryo Suryokusumo, 2007, Studi Kasus Hukum Internasional, Tata Nusa, Jakarta.

Wallace,Rebecca M., 1993, Internasional Law/Hukum Internasional, (Penerjemah Bambang Arumanadi), Cetakan 1. IKIP Semarang Press, Semarang.

Yudha Bhakti Ardhiwisastra, 1999, Imunitas Kedaulatan Negara di Forum Pengadilan Asing, Alumni, Bandung.
2003. Hukum

Internasional : Bunga Rampai,

Alumni, Bandung. 